AJIE - Asian Journal of Innovation and Entrepreneurship

(e-ISSN: 2477-0574 ; p-ISSN: 2477-3824)

Vol. 01, No. 03, September 2016

\title{
PEMBERDAYAAN MASYARAKAT DI DESA SOKO KABUPATEN PURWOREJO BERBASIS AIR BERSIH, DRAINASE, DAN LIMBAH DOMESTIK
}

\author{
Harsoyo $^{1}$, Ilya Fajar Maharika ${ }^{2}$ Widodo $^{3}$ \\ ${ }^{1}$ Program Studi Teknik Sipil, Universitas Islam Indonesia \\ ${ }^{2}$ Program Studi Arsitektur, Universitas Islam Indonesia \\ ${ }^{3}$ Program studi teknik lingkungan, Universitas Islam Indonesia \\ e-mail:835110202@uii.ac.id
}

\begin{abstract}
Soko village is a village located $8 \mathrm{~km}$ south of the town of Purworejo and in the District Bagelen. Geographically, the village of Soko is a hilly region that consists of 5 Hamlet is Krajan, Mojosongo, Sukolegok, Kebonkuning 1 and Kebonkuning 2.Permasalahan difficulty of clean water when dry and rainy seasons causing these areas clean water crisis. During the dry season the water receded and no resources at all. And when the rainy season the water became dirty due to poor drainage and yard waste from residents who go to the source of clean water.

The purpose of the implementation of KKN PPM in the village Soko Bagelen districts are: 1) The creation of a favorable environment infrastructure (water, drainage, and sewage), 2) availability of clean water for 4 hamlets, and the creation of alternative water sources through self mapping.

The target to be achieved is the creation of the role of NGOs would be willing to clean water for four hamlets (160kk), the creation of environmentally sustainable infrastructure, 3) The creation of an alternative water source.

While the methods to be used in achieving that goal is to provide guidance to communities, training, and implimentasi. This activity is supported by the Agency for Family Planning and Community empowerment purworejo district.
\end{abstract}

Keywords: Clean water, drainage, sewage, and nongovernmental

\begin{abstract}
ABSTRAK
Desa Soko merupakan desa yang yang terletak $8 \mathrm{~km}$ sebelah selatan kota Purworejo dan berada di Kecamatan Bagelen. Secara geografis, wilayah Desa Soko merupakan wilayah perbukitan yang terdiri dari 5 Dusun yaitu Krajan, Mojosongo, Sukolegok, Kebonkuning 1 dan Kebonkuning 2.Permasalahan sulitnya air bersih disaat musim kemarau dan hujan menyebabkan daerah ini mengalami krisis air bersih. Saat musim kemarau air sumber surut dan tidak ada sama sekali. Dan disaat musim penghujan air menjadi kotor dikarenakan buruknya drainase dan limbah dari pekarangan penduduk yang masuk ke sumber air bersih.

Tujuan dari pelaksanaan KKN PPM di Desa Soko kecamatan bagelen adalah 1)Terciptanya insfrastruktur lingkungan yang baik (Air bersih, drainase, dan limbah), 2)Tersedianya air bersih untuk 4 pedukuhan,dan Terciptanya sumber mata air alternatif melalui pemetaan swadaya .

Target yang ingin dicapai adalah terciptanya peran swadaya masyarakat akan kesediaan air bersih untuk 4 pedukuhan (160kk), terciptanya insfrastruktur yang berwawasan lingkungan, 3) Terciptanya sumber mata air alternatif.
\end{abstract}


Sedangkan metode yang akan dipakai dalam pencapaian tujuan tersebut yaitu dengan melakukan pendampingan kepada masayarakat, pelatihan, dan implimentasi. Kegiatan ini didukung oleh Badan Keluarga Berencana dan Pemberdayaan masyarakat Kabupaten purworejo.

Kata kunci: Air bersih, drainase, limbah, dan swadaya masyarakat

\section{LATAR BELAKANG}

Air merupakan unsur yang vital dalam kehidupan manusia. Seseorang tidak dapat bertahan hidup tanpa air, karena itulah air merupakan salah satu penopang hidup bagi manusia. Ketersediaan air di dunia ini begitu melimpah ruah, namun yang dapat dikonsumsi oleh manusia untuk keperluan air minum sangatlah sedikit. Dari total jumlah air yang ada, hanya lima persen saja yang tersedia sebagai air minum, sedangkan sisanya adalah air laut. Selain itu, kecenderungan yang terjadi sekarang ini adalah berkurangnya ketersediaan air bersih itu dari hari ke hari. Di wilayah pedesaan sering kita jumpai bahwa air bersih bercampur dengan bercampur dengan benda - benda sampah seperti plastik, sampah organic, kaleng dan sebagainya, hal tersebut akibat dari buruknya drainase dan tata kelola lingkungan yang tidak baik. Sampah dan limbah tidak terkelola dengan baik sehingga saat musim hujan air menjadi keruh. Menurut Dr. Ir. Suripin, M.Eng. $(2004 ; 7)$ drainase mempunyai arti mengalirkan, menguras, membuang, atau mengalihkan air. Secara umum, drainase didefinisikan sebagai serangkaian bangunan air yang berfungsi untuk mengurangi dan/atau membuang kelebihan air dari suatu kawasan atau lahan, sehingga lahan dapat difungsikan secara optimal. Sedangkan menurut (Suhardjono 1948:1) Drainase yaitu suatu cara pembuangan kelebihan air yang tidak diinginkan pada suatu daerah, serta cara-cara penangggulangan akibat yang ditimbulkan oleh kelebihan air tersebut.

Desa Soko merupakan desa yang yang terletak $8 \mathrm{~km}$ sebelah selatan kota Purworejo dan berada di Kecamatan Bagelen. Secara geografis, wilayah Desa Soko merupakan wilayah perbukitan yang terdiri dari 5 Dusun yaitu Krajan, Mojosongo, Sukolegok, Kebonkuning 1 dan Kebonkuning 2 dengan 4 RW dan 17 RT dengan batas wilayah meliputti:

1. Sebelah Barat: Sungai Bogowonto

2. Sebelah Utara: Desa Piji

3. Sebelah Timur: Desa Semagung

4. Sebelah Selatan: Kelurahan Clapar

Desa Soko merupakan wilayah desa di Kabupaten Purworejo yang masuk dalam kategori kemiskinan sedang, faktor ini di lihat dari tingkat ekonomi warga (penghasilan), pekerjaan, tingkat pendidikan, rumah tinggal dan kesehatan. Menurut data dari pemerintahan desa, kemiskinan di wilayah Desa Soko berjumlah 319 jiwa yang tersebar di 4 pedukuhan yaitu di pedukuhan Mojosongo, Sukolegok, Kebonkuning 1 dan Kebonkuning 2 (sumber: Lurah Desa Ruswandi, 2015). Kemiskinan di Desa Soko selain akibat dari faktor ekonomi, sosial dan pendidikan disebabkan oleh faktor insfrastruktur yang tidak memadai dengan akses jalan yang terjal dan berbukit terutama untuk 4 pedukuhan miskin di atas.

Sulitnya ketersediaan air bersih untuk konsumsi menyebabkan daerah ini 
sangat rawan akan ketersediaan air terutama di saat musim kemarau. Berdasarkan data di pemerintahan desa, faktor ini disebabkan oleh ketidak mampuan warga masyarakat dalam hal mengakses ketersediaan air bersih. Selama ini warga mendapatkan air bersih dengan mengandalkan keberadaan air bersih dari sumber mata air yang ada di atas bukit yang berjarak $1 \mathrm{~km}$, lalu dialirkan ke parit selanjutnya di distribusikan melalui selang- selang ke penduduk.

Permasalahan muncul di saat musim kemarau yaitu debit air berkurang atau tidak ada sama sekali sehingga masyarakat guna mendapatkan air dengan mengambil sisa air disungai atau wilayah lain dengan jarak tempuh 3 km di Kecamatan Purworejo. PDAM kabupaten Purworejo memberikan bantuan droping air ke warga yang mudah di jangkau dengan kendaraan atau hanya sampai di Balai Desa Soko. Waktu pemberiaan bantuan air dengan jadwal yang tidak menentu dengan jumlah tangki yang tidak sesuai dengan kebutuhan warga masyarakat.

Saat musim hujan, keberadaan air bersih di Desa Soko tersebut berubah warna menjadi keruh kecoklatan akibat dari curah hujan dan lumpur yang terbawa masuk ke dalam parit. Buruknya drainase dan limbah pemukiman menjadi faktor yang menyebabkan keruhnya air bersih di Desa Soko. Air hujan yang bercampur dengan limbah pemukiman tersebut masuk de dalam parit air bersih yang berasal dari sumber mata air yang dibuat oleh warga masyarakat. Berdasarkan identifikasi masalah tersebut, permasalahan tersebut di sebabkan akibat dari:
1. Ketidaktahuan warga masyarakat dalam mengelola sumber mata air

Sumber mata air selama ini dipergunakan untuk 344 KK untuk 4 wilayah Dusun, masyarakat tidak mampu mengukur ketersediaan air dan manajemen pengelolaannya sehingga pendistribusian air kerumah penduduk tidak seimbang, semakin jauh maka semakin sedikit mendapatkan pasokan air bersih.

\section{Buruknya drainase lingkungan}

Drainase lingkungan yang berfungsi sebagai aliran hujan tidak berfungsi sebagai mana mestinya, dikarenakan masyarakat membuat drainase yang tidak di tata kelola yang baik, akibatnya saat hujan air mengalir ke pekarangan penduduk, dan menyebabkan tergerusnya tanah akibat debit air hujan yang tidak terkontrol

\section{Kendala Pembuangan Limbah}

Limbah keluarga baik cair dan padat (sampah) di buang di pekarangan rumah dengan sisitem limbah cair dialirkan begitu saja, dan limbah sampah di tumpuk di jugangan (lubang yang di buat ditanah) setelah itu dibakar jika sudah menumpuk

\section{Kurangnya Pemanfaatan air hujan}

Pemanfatan air hujan tidak dimanfaatkan dengan baik oleh warga masyarakat, air hujan terbuang begitu saja, tidak pernah ada pengelolaan air hujan untuk kebutuhan, Air hujan yang dikelola dengan baik dapat memenuhi akan ketersedian air dan juga dapat di gunakan sebagai kebutuhan peningkatan ekonomi warga melalui pembuatan kolam ikan,dan perkebunan.Tidak adanya sarana sumur resapan dan biopori mengakibatkan air tidak terserap oleh 
tanah. Kurangnya pengetahuan tentang pemanenan air hujan warga masyarakat menjadi factor yang menyebabkan pemanfaatan air hujan tidak dapat dimanfaatkan dengan baik saat musim kemarau sebagai pemenuhan kebutuhan ketersediaan air.

5. Ketidak mampuan pemetaan sumber mata air alternatif

Warga masyarakat selama ini mengandalkan kebutuhan akan air melalui pemanfaatan air yang bersumber di atas bukit. Ketidak mampuan warga dalam mencari sumber air alternatif menyebabkan kurangnya ketersediaan air

\section{METODE ANALISIS}

Berdasarkan permasalahan tesebut diatas pengabdi dan mitra masyarakat sepakat menyelesaikan program prioritas permasalahan dan keberlanjutan program dengan metode pendampingan perbaikan insfrastruktur lingkungan (air bersih, drainase, dan limbah) berbasis swadaya masyarakat, yang bertujuan peningkatan partisipasi masyarakat dan swadaya dari masyarakat dalam upaya dalam perbaikan insfrastruktur lingkungan di Desa Soko Kabuapten Purworejo, sehingga prioritas program yang akan diselesaikan dalam KKN PPM ini sebagai berikut.

Tabel 2. Prioritas kegiatan program KKN PPM di Desa Soko Purworejo

\begin{tabular}{|c|c|c|c|}
\hline No & Aspek & Permasalahan & Prioritas program \\
\hline 1. & $\begin{array}{c}\text { Air } \\
\text { Bersih }\end{array}$ & $\begin{array}{l}\text { 1. Ketidakmampuan masyarakat } \\
\text { dalam mengelola sumber mata } \\
\text { air } \\
\text { 2. Ketidak mampuan warga dalam } \\
\text { pemanfaatan air hujan } \\
\text { 3. Ketidakmampuan warga } \\
\text { masyarakat dalam memetakan } \\
\text { sumber air alternatif } \\
\text { 4. Ketidakmampuan } \\
\text { masyarakat dalam menghitung } \\
\text { kebutuhan air dengan jumlah } \\
\text { penduduk } \\
\text { 5. Air sumber hanya di alirkan ke } \\
\text { parit tidak bersemen sehingga } \\
\text { air akan mudah meresap } \\
\text { sebelum sampai } \\
\text { penampungan penduduk }\end{array}$ & $\begin{array}{l}\text { 1. Pendampingan perbaikan } \\
\text { saluran didistribusi air sumber } \\
\text { 2. Pendampingan pengelolaan } \\
\text { drainase } \\
\text { lingkungan berwawasan } \\
\text { 3. Pendamping gerakan } \\
\text { pemanenan air hujan } \\
\text { 4. Pendampingan pemetaan } \\
\text { sumber mata air alternatif }\end{array}$ \\
\hline 2. & Drainase & $\begin{array}{l}\text { 1. Drainase air hujan dibuat } \\
\text { sembarangan } \\
\text { 2. Drainase dibuat dengan metode } \\
\text { parit yang tidak saling } \\
\text { berhubungan } \\
\text { 3. Air hujan terbuang percuma }\end{array}$ & 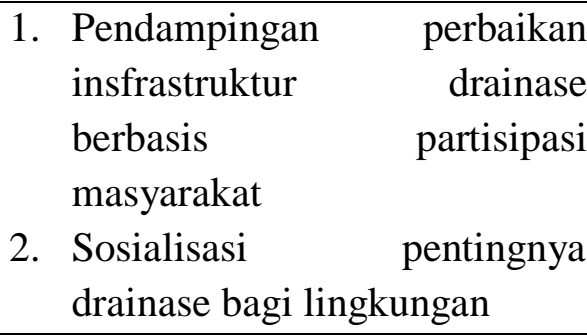 \\
\hline
\end{tabular}




\begin{tabular}{|c|c|c|c|}
\hline & & $\begin{array}{l}\text { 4. Muara dari drainase harusnya } \\
\text { kesungai akan tetapi limpasan } \\
\text { air masuk ke pekarangan } \\
\text { 5. Tidak adanya drainase sumur } \\
\text { resapan }\end{array}$ & 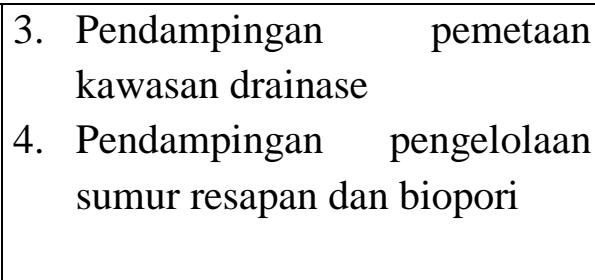 \\
\hline 3. & Limbah & $\begin{array}{l}\text { 1. Tidak ada limbah keluarga yang } \\
\text { terkelola dengan baik } \\
\text { 2. Limbah padat (sampah) di } \\
\text { buang disekitar pekarangan } \\
\text { rumah } \\
\text { 3. Limbah cair tidak dibuatkan } \\
\text { penampungan tertutup }\end{array}$ & $\begin{array}{l}\text { 1. Sosialisasi pengelolaan limbah } \\
\text { keluarga untuk kesehatan } \\
\text { 2. Eduskasi pentingnya } \\
\text { penanganan limbah keluarga } \\
\text { berbasis keluarga } \\
\text { 3. Pengelolaan limbah cair } \\
\text { berbasis ecotech garden }\end{array}$ \\
\hline
\end{tabular}

Teknologi/Metode yang Diterapkan untuk Mengatasi Permasalahan

Dalam mengatasi permasalahan tersebut di atas maka metode yang digunakan supaya program dapat berkelanjutan dengan melakukan pendampingan, pelatihan, implementasi, dan aplikasi, sehingga kegiatan tersebut dapat di uraikan sebagai berikut:

1. Pendampingan peningkatan kapasitas SDM dalam pengelolaan sumber mata air

2. Pendampingan pengelolaan drainase berwasan lingkungan

3. Pendampingan gerakan pemanenan air hujan

4. Pendampingan pemetaan sumber mata air alternatif

5. Pendampingan perbaikan insfrastruktur drainase berbasis partisipasi masyarakat

6. Pendampingan pengelolaan sumur resapan dan biopori

7. Eduskasi pentingnya penanganan limbah keluarga berbasis keluarga

\section{HASIL DAN PEMBAHASAN}

\section{Realisasi Kegiatan}

Program kegiatan KKN UII dilaksanakan melalui beberapa tahapan, yaitu tahap persiapan, tahap pelaksanaan serta tahap evaluasi dan pelaporan.

\section{Tahapan Persiapan}

Untuk pelaksanaan KKN selalu diawali dengan tahapan persiapan, yaitu mempersiapkan calon mahasiswa KKN dan mempersiapkan pembekalan bagi mahasiswa.

\section{Seleksi Mahasiswa}

Tahap persiapan awal adalah menyeleksi mahasiswa pendaftar $\mathrm{KKN}$ melalui seleksi administrasi serta test kesiapan pengetahuan dan kecakapan. Seleksi ini dimaksudkan untuk mendapatkan mahasiswa yang dibutuhkan sesuai dengan tema program KKN PPM. Tujuan seleksi ini dilakukan untuk menemukan mahasiswa yang sesuai harapan program. Seleksi dilakukan pada waktu 21 s/d 23 Juni 2016.

\section{Pembekalan Mahasiswa}

Pelaksanaan pembekalan ini bertujuan untuk mendekatkan pemahaman mahasiswa terhadap kebutuhan tema program yang akan dilaksanakan oleh mahasiswa. Tahapan pembekalan mahasiswa KKN PPM berdasarkan disesuaikan kebutuhan tema program, 
yaitu pembekalan materi ilmu terapan sesuai disiplin ilmu masing-masing mahasiswa. Mulai materi umum, materi administrasi, materi kemasyarakatan, materi kewirausahaan, materi kecakapan khusus dan materi manajemen dan program KKN PPM. Untuk pembekalan menggunakan materi standar 5 bidang, namun isi materi disesuaikan "tema yang diangkat dalam program suatu wilayah". Pelaksanaannya dilakukan pada 23 s/d 24 Juli 2016, meliputi:

1. Bidang " Pengembangan Industri Ekonomi Kreatif Berbasis Wirausaha dan Etika Global.
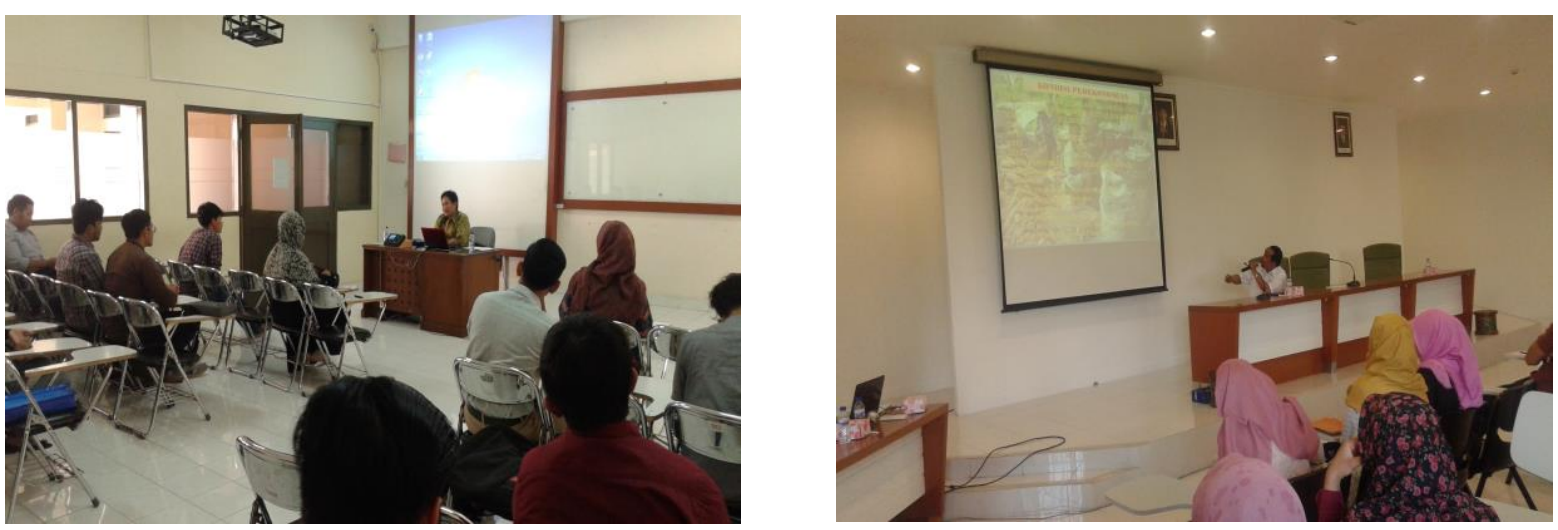

Gambar 1. Kegiatan Pembekalan dan Kewilayahan

\section{Pengarahan, Pelepasan dan Penerjunan Mahasiswa}

Pelaksanaan pengarahan, pelepasan dan penerjunan mahasiswa ini dimaksudkan untuk pembekalan umum

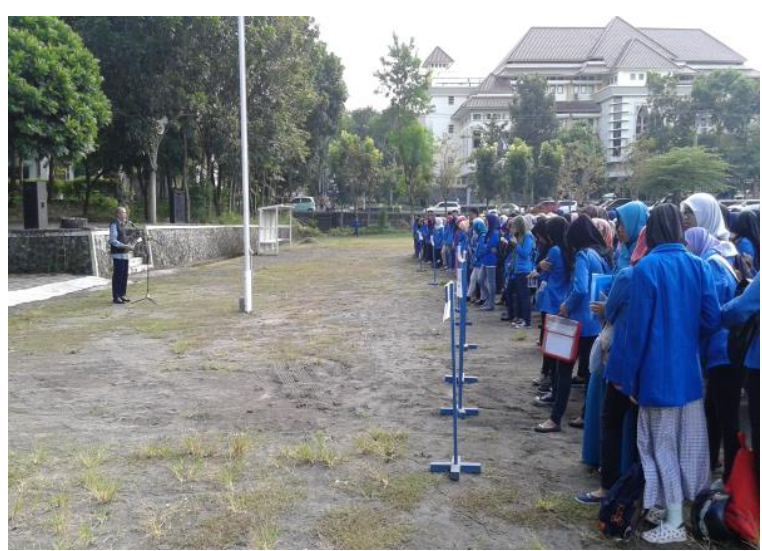

2. Bidang "Pengembangan Virtual Environment (VE) untuk pendidikan, pemerintahan dan bisnis desa"

3. Bidang "Pengembangan Kawasan Pedesaan untuk peningkatan Kesejahteraan Masyarakat".

4. Bidang "Pengembangan Lingkungan dan Permikuman yang Cerdas, Lestari dan Berbasis Potensi wilayah"

5. Bidang "Kemasyarakatan dan Kewilayahan" oleh pejabat Rektorat untuk memberikan motivasi, dukungan dan arahan selama pelaksanaan KKN, diharapkan mahasiswa mampu menjaga diri, bersosialisasi dan bertugas menyelesaikan kegiatan $\mathrm{KKN}$ dengan baik dan benar.

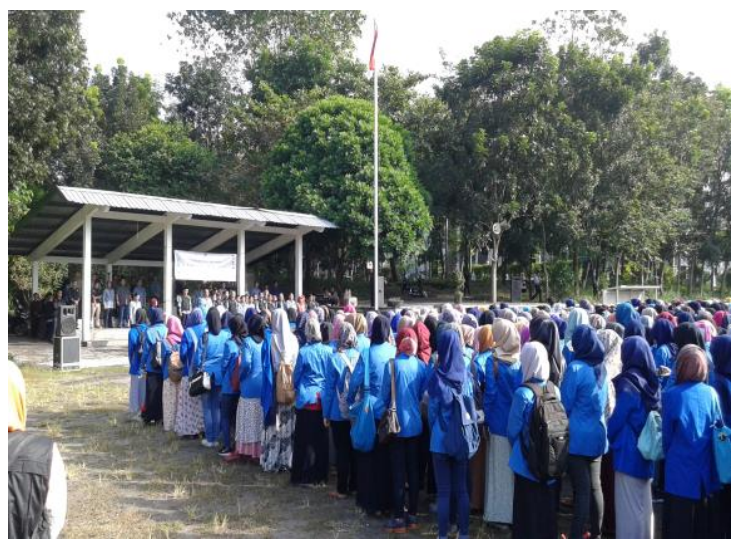


Gambar 2. Kegiatan Pengarahan dan Pelepasan Mahasiswa KKN-PPM
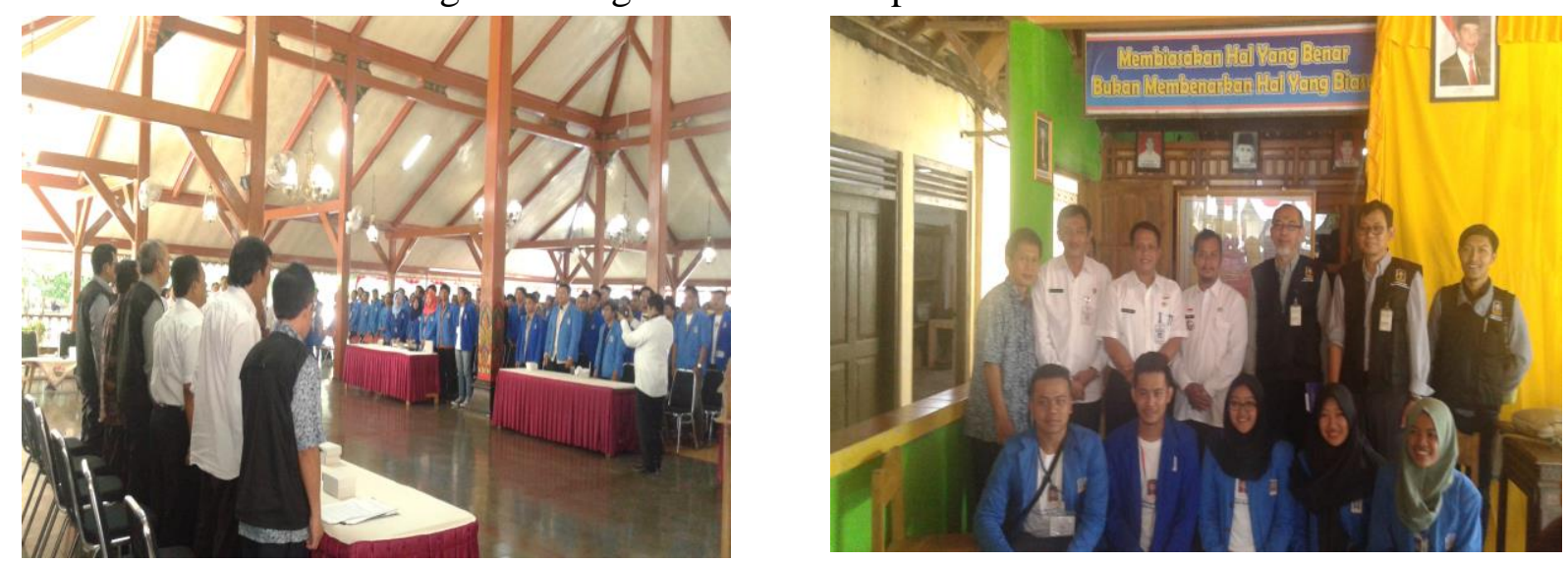

Gambar 3. Penerimaan mahasiswa KKN-PPM di Desa Soko bersama Bupati Purworejo

\section{Tahapan Realisasi Program}

Untuk pelaksanaan KKN telah dilakukan koordinasi dan sosialisasi program-program kepada masyarakat sasaran, yaitu mempersiapkan masyarakat sasaran untuk terlibat kegiatan yang disepakati bersama masyarakat.
Mahasiswa KKN menjalankan program kegiatan dimulai dari proses pertemuan bersama masyarakat sasaran, dimaksud mewujudkan atau membangun kesepahaman dan kesepakatan dalam kerjasama.

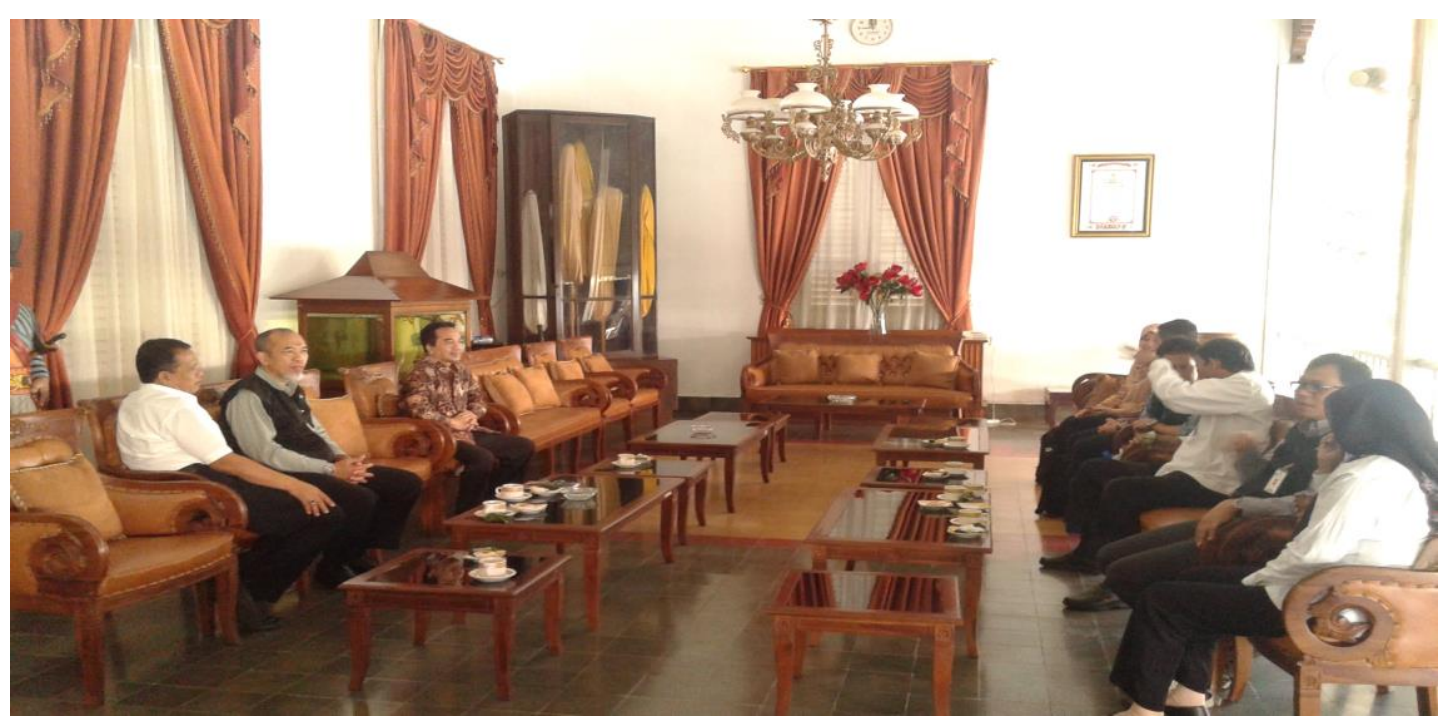

Gambar 4. Koordinasi Pelaksanaan KKN-PPM dengan Pemerintah Kabupaten Purworejo

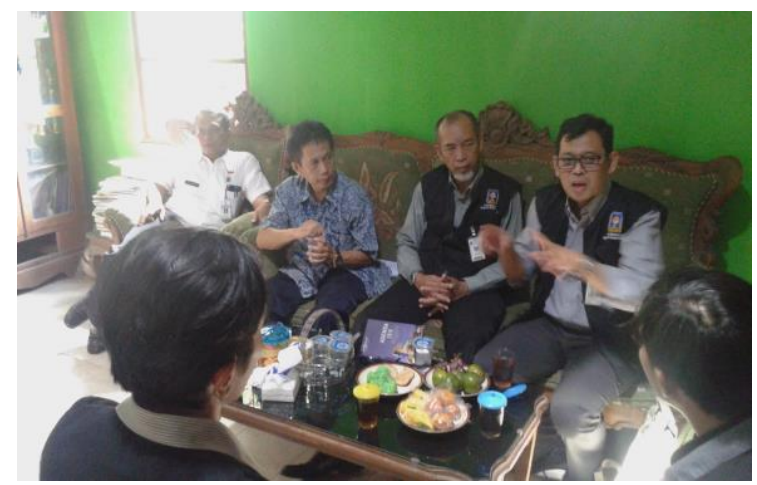


Gambar 5. Sosialisasi ke Masyarakat Penerima Hibah KKN-PPM

Pendampingan peningkatan kapasitas SDM masyarakat dalam membuat sumur bor

Kegiatan ini merupakan tindak lanjut dari hasil pertemuan dan sosialisasi jika di Desa Soko Kabuapaten Purworejo

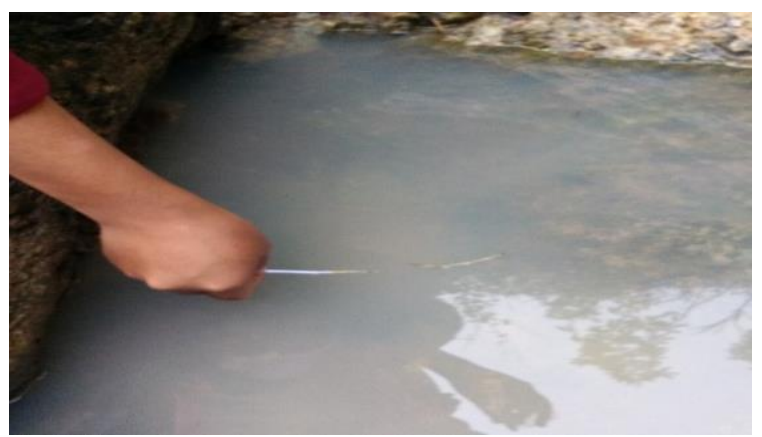

mengalami krisis air bersih. Air sumber yang dekat dengan sungai sangat keruh akibat dari limbah dan sampah yang masuk ke dalam sumur. Saat musim kemarau air sumur tidak dapat memenuhi kebutuhan warga masyarakat.

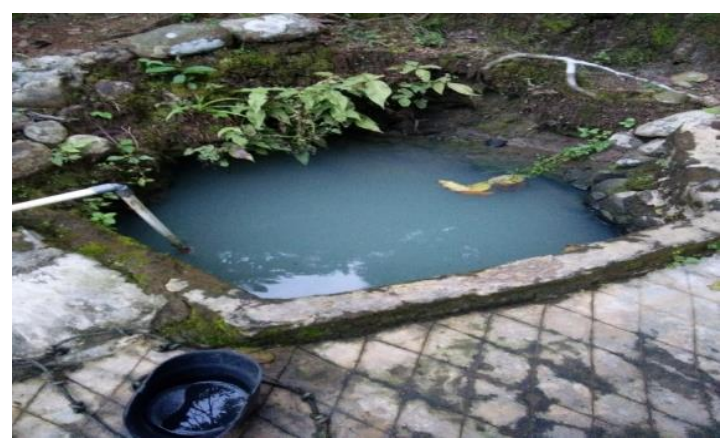

Gambar 6. Kondisi sumur dan mata air warga di Desa Soko Purworejo
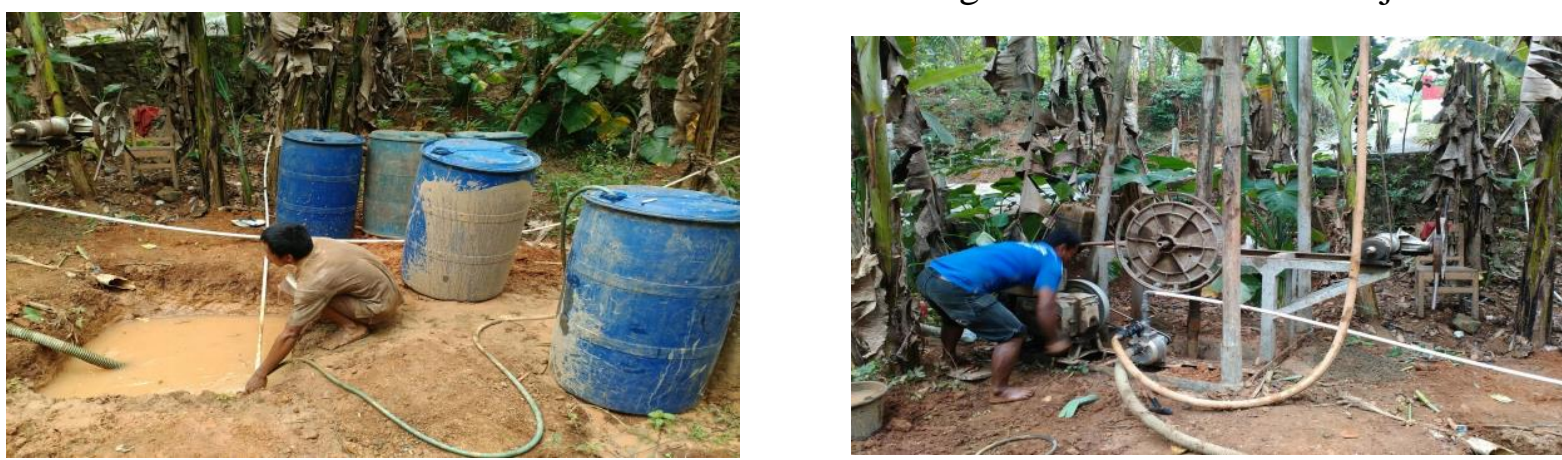

Gambar 7. Pembuatan sumur bor di Desa Soko Purworejo

Pendampingan pengelolaan drainase berwawasan Lingkungan

Drainase di Desa Soko Purworejo selama ini belum terkelola dengan baik dengan adanya gambar perencanaan yang sudah

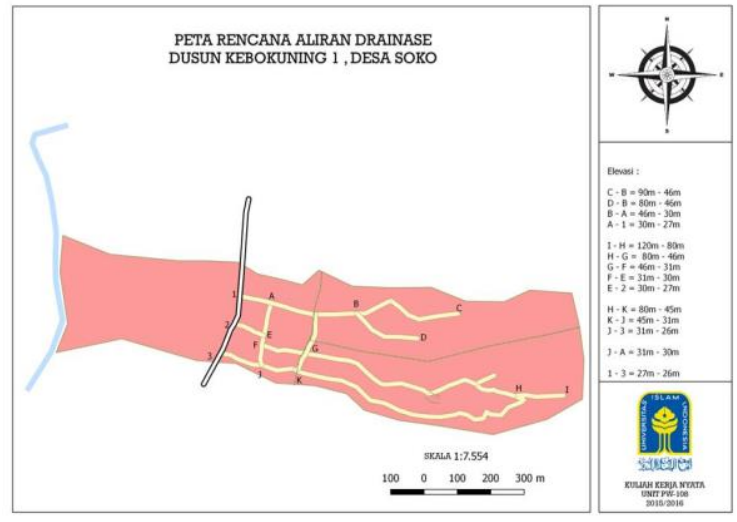

ada. Akibatnya drinase yang ada saat ini jika musim penghujan tidak berfunsi dengan baik dan berakibat airnya masuk ke dalam sumur warga.

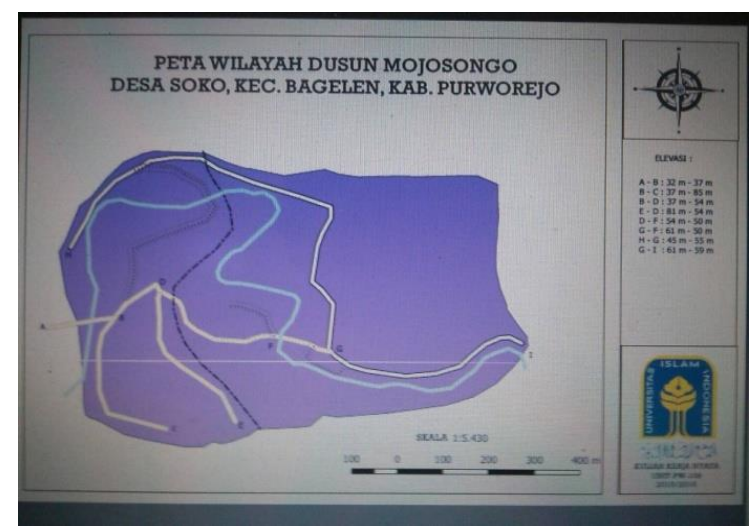

Gambar 8. Masterplan Drainase 
Pendampingan gerakan pemanenan air hujan

Masyarakat di Desa Soko Kabuapaten Purworejo belum menyadari tentang

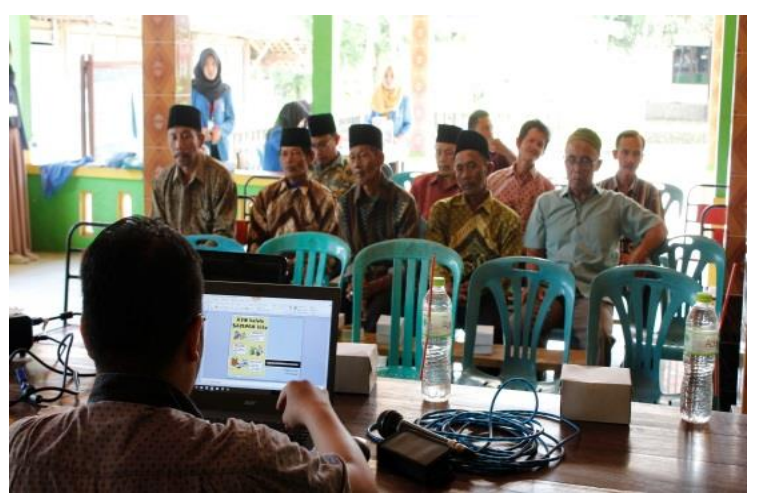

pentingnya gerakan pemanenan air hujan. Hal tersebut akibat dari ketidak tahuan warga masyarakat jika air hujan dapat dimanfaatkan di saat musim kemarau

Gambar 9. Sosialisasi gerakan pemanenan air hujan

Pendampingan pemetaan sumber mata air alternatif

Keterbatasan masyarakat dalam mencari alternatif sumber mata ir menjadikan

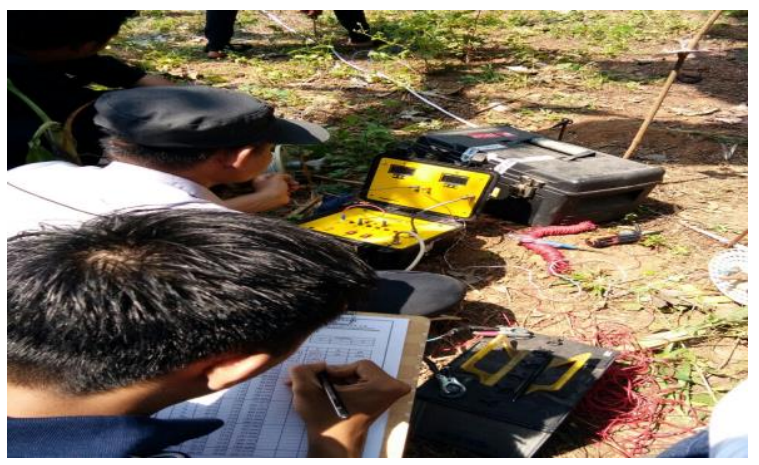

kegiatan ini sangat bermanfaat bagi masyarakat di Desa Soko. Hasil dari kegiatan ini berupa pemetaan lokasi tanah yang memiliki sumber mata air.

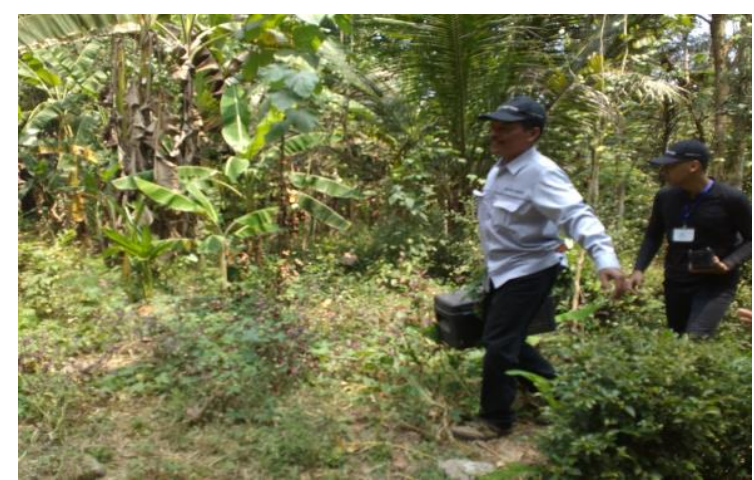

Gambar 10. Pemetaan sumber mata air alternatif

\section{Pendampingan mapping uji sampling kualitas air}

- Lokasi 1: Berada di samping lereng

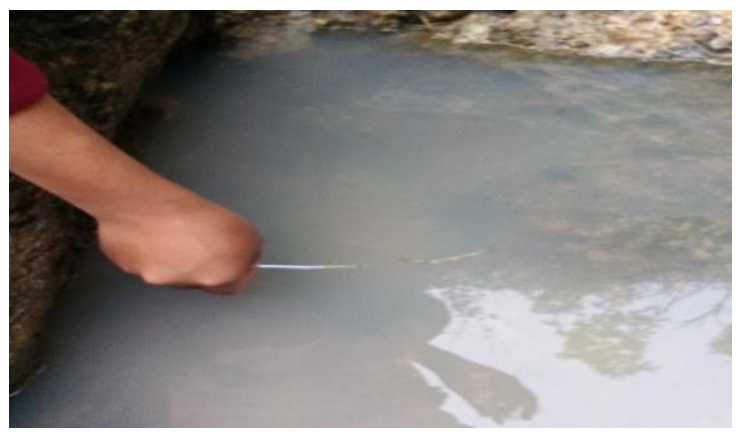

Uji klasifikasidi beberapa titik air di daerah Watu Bungkus:

Gambar 11. Sumber Air Watu Bungkus 1, pH =6 
- Lokasi 2: Berada di dalam hutan
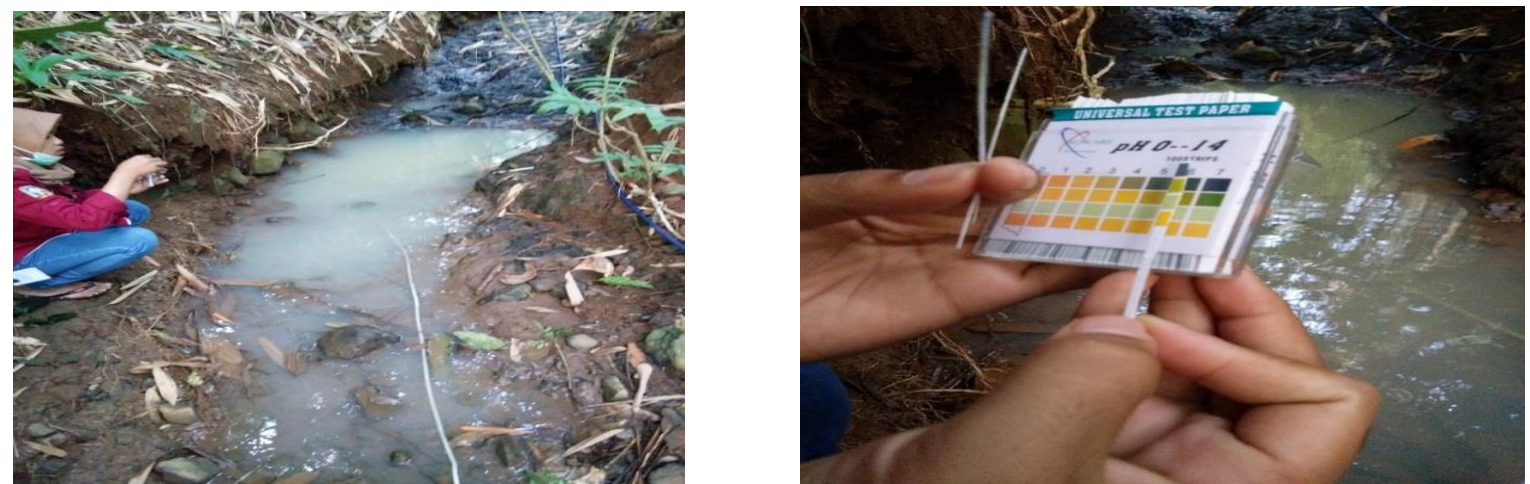

Gambar 12. Sumber Air Watu Bungkus 2, $\mathrm{pH}=5$

- Lokasi 3: Berada di dalam hutan
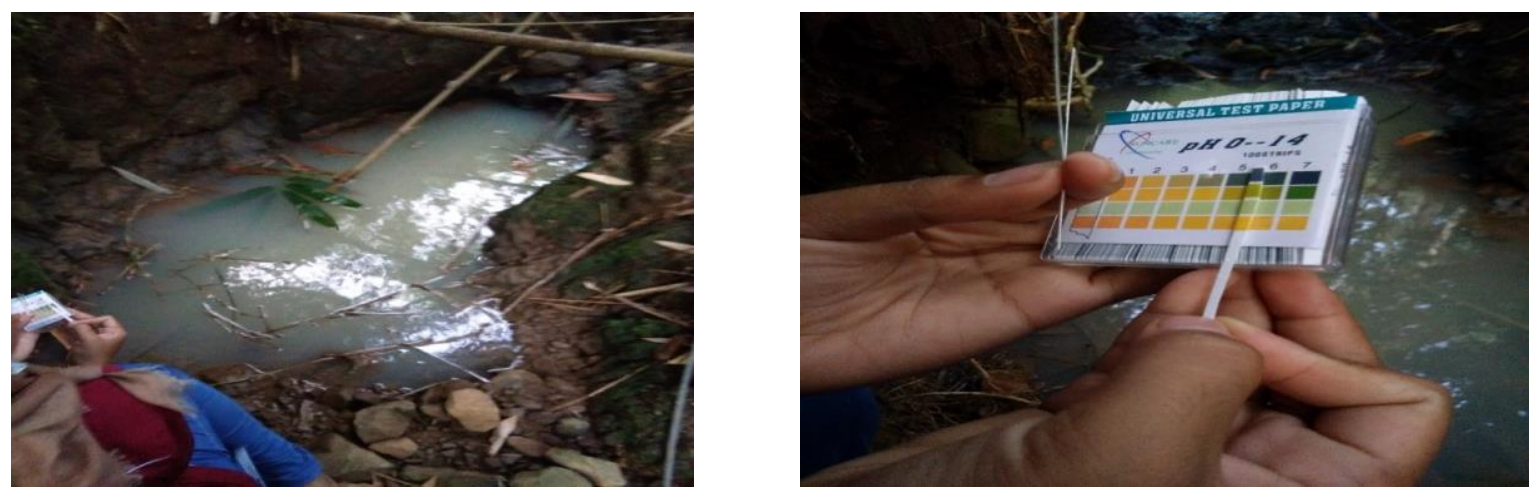

Gambar 13. Sumber Air Watu Bungkus 3, pH = 5

a. Lemah putih

Berdasarkan informasi yang didapat dari warga sekitar bahwa terdapatsumber mata air di daerah lemah putih, dimana sumber air tersebut tidak pernah surut walaupun musim kemarau, hanya saja ketika air mulai didistribusikan kepada warga air tersebut akan surut dan akan kembali seperti semula dalam jangka waktu 2-4 jam.

Klasifikasi Air:

- Lokasi : Lemah Putih
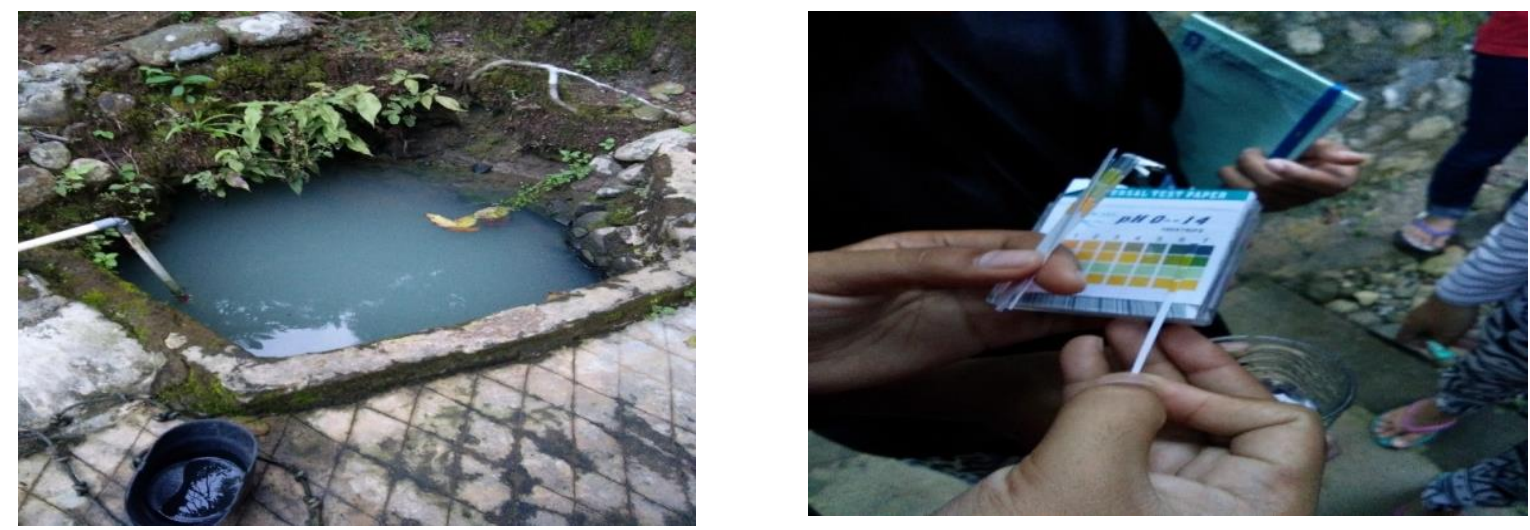

Gambar 14. Sumur lemah putih, $\mathrm{pH}=7$ 
a. Sumur bor pak sampar

Sumur ini mulai di bor pada tanggal 12 Desember 2012, dengan jangka waktu

- Lokasi: RT 02/ RW 05
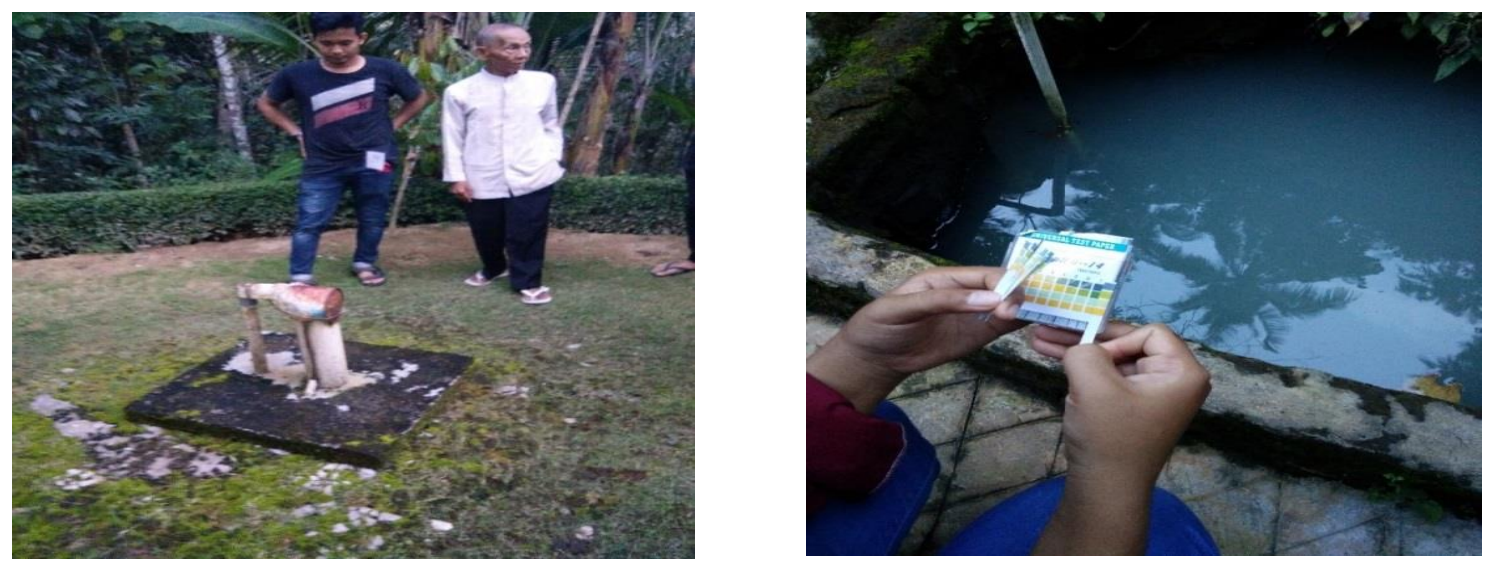

Gambar 15. Sumur Bor Pak Sampar, $\mathrm{pH}=7$

b. Sumur salak

Sumur ini dibangun pada tahun 1973, sumur ini memiliki kedalaman 2 meter dengan jumlah masyarakat yang menggunakan sumber ini adalah sebanyak 13-15 warga.Sumber air yang berasal dari sumur salak belum pernah surut walaupun pengeboran yaitu selama 23 hari. Sumur ini memiliki kedalaman total 56 meter.

- Lokasi: RT 01/05 dusun Kebokuning II

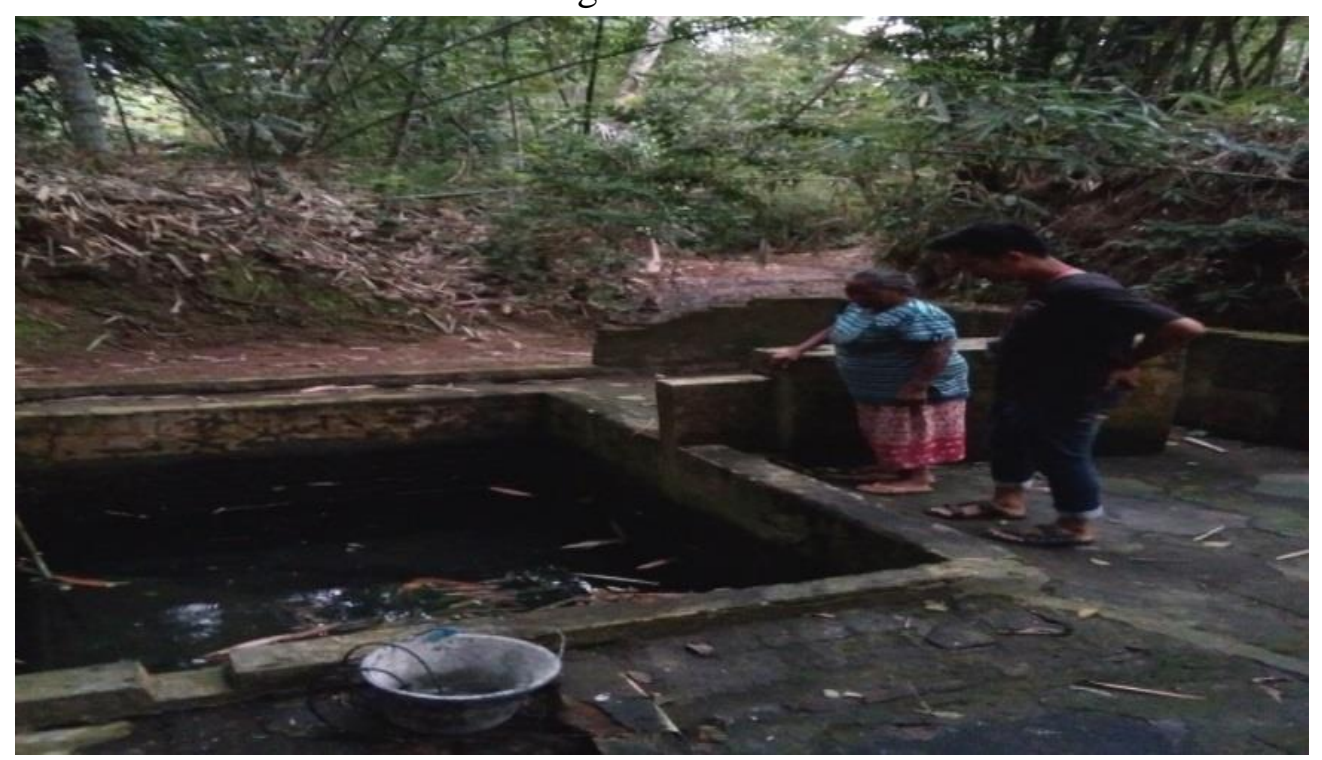

Gambar 16. Sumur Salak, pH 6-7 


\section{KESIMPULAN}

Dalam pelaksanaan laporan kegiatan pengabdian kepada masyarakat dalam bentuk program pendampingan perbaikan insfrastuktur lingkungan (air

bersih,drinase,limbah) berbasis swadaya masyarakat ini adalah dapat disimpulkan sebagai berikut:

1) Pelaksanaan PPM ini mendapatkan respon yang positif dari pemerintah desa dan pemerintah kabupaten purworejo.

2) Pelaksanaan KKN-PPM ini menghasilkan satu sumur air bersih di Desa Soko

3) Hasil dari perencanaan /masterplan drainase akan ditindak lanjuti dengan program desa pada tahun 2017

\section{SARAN}

Saran dalam pelaksanaan kegiatan PPM pendampingan perbaikan insfrastuktur lingkungan (air bersih,drinase,limbah) berbasis swadaya masyarakat ini dapat ditindak lanjuti dengan kegiatan yang serupa sehingga keberadaan akan air bersih di Desa Soko Kabupaten Purworejo dapat terwujud dengan baik.

\section{UCAPAN TERIMA KASIH}

Penulis mengucapkan terima kasih kepada Direktorat Riset dan Pengabdian masyarakat (DRPM), Kementerian Riset, Teknologi dan Pendidikan Tinggi yang telah memberikan dana hibah untuk pelaksanaan kegiatan Pengabdian Masyarakat KKN-PPM (Kuliah Kerja Nyata-Program Pemberdayaan Masyarakat) ini.

\section{DAFTAR PUSTAKA}

Safi'i, M., (2011), Ampih Kemiskinan; Model Kebijakan Penuntasan Kemiskinan dalam Perspektif Teori dan Praktik, Cet. ke-1, Averroes Press: Malang.

Sahudiyono (2009), Memberdayakan Masyarakat Pesisir dengan Pendekatan Program Pemberdayaan Ekonomi Masyarakat Pesisir (PEMP), Jurnal Riset Daerah BAPEDA Bantul, 7(3), 1169-1189.

Jayadi, R. 2000. Pengantar Hidrologi, Universitas Gadjah Mada, Yogyakarta.

Kodoatie, R.J dan Sugiyanto, Banjir, Perpustakaan Mahasiswa, Yogyakarta.

Kusumo, W. 2009.Penanganan Sistem Drainase Kecamatan Jati Kabupaten Kudus. Universitas Diponegoro, Semarang.

Nadajadji, A. 2008.Aplikasi Storm Water Management Model Pada DAS Deluwang Jawa Timur, Vol.1 pp.1-2, Jawa Timur.

Palar, R.T dkk. 2013. Studi Perbandingan Antara Hidrograf SCS (Soil Conservation Service) dan Metode Rasional Pada DAS Tikala, Jurnal Teknik Sipil Vol. 1 No. 3, Manado.

Sismanto.2009. Analisa Lahan Kritis Sub DAS Riam Kanan DAS Barito Kabupaten Banjar Kalimantan Tengah, Jurnal Aplikasi Vol.6 No.1, Surabaya. 